\title{
A 10-year-old girl with Joubert syndrome and chronic kidney disease and its related complications
}

\author{
Chong Tian ${ }^{1 \#}$, Jiaxiang Chen ${ }^{1,2 \#}$, Xing Ming ${ }^{1}$, Xianchun Zeng ${ }^{1}$, Rongpin Wang ${ }^{1}$ \\ ${ }^{1}$ Department of Medical Imaging, Guizhou Provincial People’s Hospital, Guiyang, China; ${ }^{2}$ Guizhou University School of Medicine, Guiyang, China \\ \#These authors contributed equally to this work.
}

Correspondence to: Rongpin Wang. Department of Medical Imaging, Guizhou Provincial People's Hospital, Zhongshan East Road 83, Guiyang 550002, China. Email: wangrongpin@126.com.

Submitted Aug 05, 2020. Accepted for publication Apr 01, 2021.

doi: 10.21037/qims-20-943

View this article at: http://dx.doi.org/10.21037/qims-20-943

\section{Introduction}

Joubert syndrome (JS) is a rare genetic disorder of recessive neurodevelopmental disorder characterized by distinctive cerebellar vermis and mid-hindbrain hypoplasia/dysplasia called the "molar tooth sign" (MTS) (1). Patients present with symptoms characteristic of hypotonia in infancy and later develop ataxia, ocular motor apraxia, and may also present with developmental delays or intellectual retardation. Defined by the central nervous system features, JS also affects many other organs, such as the kidneys, liver, and bones. It is challenging to diagnose JS when patients present with atypical clinical features for other organ systems. In this paper, we report a case of a 10-year-old female with atypical presentation of JS (type 7), which was diagnosed by genome sequencing analysis. The patient was diagnosed with chronic kidney disease (CKD) and experienced complications, including renal anemia and renal osteoarthropathy. Magnetic resonance imaging (MRI) of her axial brain showed the MTS. This case emphasizes the importance of comprehensive evaluations of JS by clinical diagnosis, imaging, and genetic testing.

\section{Case presentation}

A 10-year-old female was admitted to our hospital. She complained that she had experienced pain in her knees and ankles for 3 months. The pain was severe, especially when walking quickly and going downstairs. The pain was relieved when she rested. Tenderness of the bilateral knees and ankles was tolerated without redness, swelling, fistula, or sinus tract surrounding the skin. She had been healthy in the past, and her academic performance was moderate. She was a picky eater and had a mild short stature but showed no other development dysplasia. Nystagmus, oculomotor apraxia, hypotonia, and abnormal breathing patterns were not observed. Concerning the patient's family history, her mother and father appeared normal, but their first child died of renal failure at the age of 4 , their second-born twin sons died in the perinatal period (causes unknown), and a third male child also died of renal failure at the age of 9 . The patient had a 7-year-old younger brother who was currently alive, who had good health and normal intelligence.

Laboratory examinations showed negative anti-nuclear antibody profiles. Routine blood tests showed that the patient's white blood cell count was $6.03 \times 10^{9} / \mathrm{L}$, red blood cell count was $2.77 \times 10^{12} / \mathrm{L}$, hemoglobin level was $76.0 \mathrm{~g} / \mathrm{L}$, blood platelet level was $140 \times 10^{9} / \mathrm{L}$, the neutrophil percentage was $56.5 \%$, and lymphocyte percentage was $30.3 \%$. Concerning kidney function, the urea level was $18.05 \mathrm{mmol} / \mathrm{L}$ (reference range, $2.5-6 \mathrm{mmol} / \mathrm{L}$ ), the creatinine level was $664 \mu \mathrm{mol} / \mathrm{L}$ (reference range, $41-73 \mu \mathrm{mol} / \mathrm{L}$ ), and the estimated glomerular filtration rate was 8 (CKD-EPI $\geq 90)$. The patient's hepatic function showed no abnormalities, and the full-type parathyroid hormone level was $1,057 \mathrm{pg} / \mathrm{mL}$ (reference range, $15-68.3 \mathrm{pg} / \mathrm{mL}$ ). An ultrasound examination of the abdomen showed scattered cysts in both kidneys and a slight expansion of the renal pelvis and calyces (see Figure 1).

Given the patient's family history and renal performance, 
the doctor suspected genetic-related diseases and suggested the patient and her family members undergo genetic testing. The results of the trio whole-exon gene detection V4 by high-throughput sequencing showed that the patient's RPGRIP1L gene [which has several related diseases, including $\mathrm{COACH}$ syndrome, Meckel syndrome (type 5), and JS (type 7)] had one homozygous mutation. Both the patient's parents and her 7-year-old younger brother had a heterozygous variation at the $\mathrm{c} 2018 \mathrm{G}>\mathrm{A}$ (P.G727D) site and thus were recessive carriers. The girl's final diagnosis was JS with renal diseases [stage 5 CKD, renal anemia (moderate), renal osteoarthropathy, and renal cysts].

The doctor advised the patient to undergo a head MRI examination to determine if there were any brain malformations. The MRI of the brain showed that the fourth ventricle communicated with the posterior cranial fossa (see Figure $2 A$ ), inferior cerebellar vermis hypoplasia (Figure $2 B$ ), slightly thickened and elongated superior cerebellar peduncles

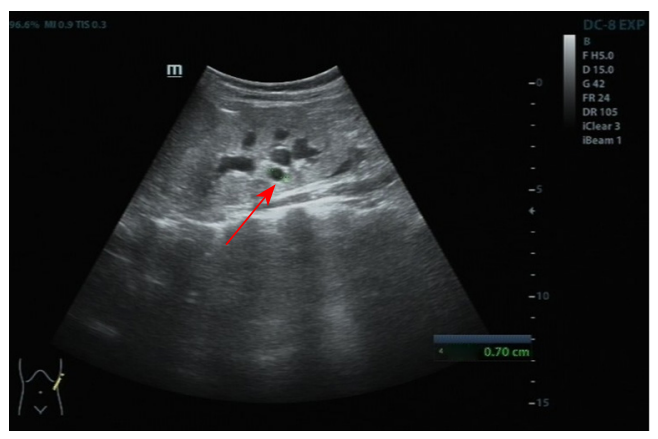

Figure 1 An ultrasound examination of the abdomen showed a cyst in the left kidney and a slight expansion of the renal pelvis and calyces.
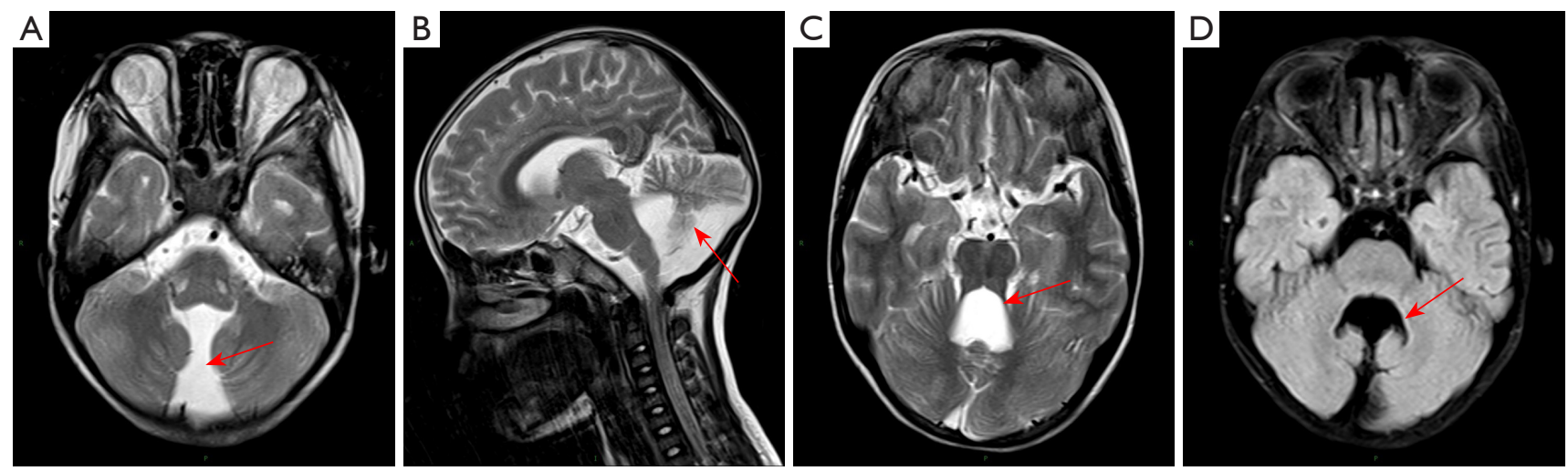

Figure $2 \mathrm{MRI}$ of the brain showed that the fourth ventricle communicated with the posterior cranial fossa (A, the thick arrow), the cerebellar vermis hypoplasia (B, the arrow), the molar tooth sign (C, the thick arrow), and the bat-wing sign (D, the thick arrow). MRI, magnetic resonance imaging.

with a horizontal orientation, which was similar to the MTS (see Figure 2C), slightly thickened superior cerebellar peduncles, and that the fourth ventricle had a convex roof, which had the appearance of a "bat-wing sign" (see Figure 2D). No other neural malformations were discovered.

\section{Discussion}

JS is a rare genetic recessive neurodevelopmental disorder with a live-birth prevalence between 1 in 80,000 and 1 in 100,000; however, it should be noted that these figures may represent an underestimation $(2,3)$. Joubert first described it in 1969 as a distinctive cerebellar and brain stem malformation accompanied by episodic tachypnea or apnea and/or atypical eye movements, hypotonia, developmental delays, or cognitive dysfunction. In general, the clinical features of JS are evident in infancy and include nystagmus, oculomotor apraxia, and abnormal breathing patterns. In children or adults, common symptoms include ataxia and/or cognitive impairment. In addition to these core features, most JS patients are also found to have systemic abnormalities, such as kidney, liver, and bone abnormalities. Thus, JS is not simply a neurological disease, but a multi-system disease and some comorbidities are progressive, such as those of fibrocystic kidney disease, which often develops into chronic renal failure in children and adolescents (4-6). In the present case, the patient had no neurological symptoms, which may be related to her having less severe neurodevelopmental abnormalities or the neurological symptoms not having developed thus far. As the patient's main complaint was of pain in her knees and ankles, which was caused by renal osteoarthropathy, she did not undergo a brain MRI 
examination before genetic testing. Thus, the doctor did not consider a diagnosis of $\mathrm{JS}$ with renal diseases.

To date, pathogenic variants in 34 autosomal and one $\mathrm{X}$-linked gene are known to cause JS. A molecular diagnosis of JS can be established in about $62-94 \%$ of individuals with a clinical diagnosis of JS by 35 genes (7). In this case, the patient's gene sequencing revealed a homozygous mutation in the RPGRIP1L gene, which is located at chromosome 16q12.2 and comprises 26 exons and 3,948 bp, and encodes a 1315 -amino acid protein. It is related to hedgehog signaling and cilia formation. The cilia structure can mediate the generation and transmission of various biological cell signals and is related to cyst formation $(8,9)$. More severe truncating variants are associated with the lethal Meckel syndrome phenotype, while less severe variants cause JS (10). According to the Online Mendelian Inheritance in Man, the RPGRIP1L gene is the causative gene of JS (type 7) and Meckel syndrome (type 5; however, Meckel syndrome shows polycystic kidney and occipital brain bulging, the axial position of multi-finger deformity and most patients with this syndrome die in the perinatal period (10). This patient's main clinical manifestations were CKD and its related complications, including renal anemia and renal osteoarthropathy. The patient's comprehensive diagnosis was JS (type 7) with renal disease.

MRI has significant value in diagnosing JS. In 1997, Maria described a typical MTS on an axial MRI of the disease characterized by an abnormally deep interpeduncular fossa, prominent, straight, and thickened superior cerebellar peduncles hypoplasia of the vermis. The axial MRI showed thick superior cerebellar peduncles, and the fourth ventricle had a convex roof. The appearance of which has been described as a "bat-wing sign". The coronal MRI showed thickened superior cerebellar peduncles with a sagittal cleft. The appearance of which has been described as a "buttock sign". Diffusion tensor MRI tractography shows horizontally oriented superior cerebellar peduncles and an absence of decussation of the superior cerebellar peduncles and corticospinal tract (11-13).

In conclusion, we reported a case in which a patient presented with no obvious neurological symptoms but the first CKD symptom. This case study emphasizes the importance of comprehensive evaluations for JS combined with clinical, imaging, and genetic testing.

\section{Acknowledgments}

Funding: None.

\section{Footnote}

Conflicts of Interest: All authors have completed the ICMJE uniform disclosure form (available at http://dx.doi. org/10.21037/qims-20-943). The authors have no conflicts of interest to declare.

Etbical Statement: The authors are accountable for all aspects of the work in ensuring that questions related to the accuracy or integrity of any part of the work are appropriately investigated and resolved. All procedures performed were following the ethical standards of the institutional and/or national research committee(s) and with the Declaration of Helsinki (as revised in 2013). Written informed consent was obtained from the patient's parents to publish this manuscript and accompanying images.

Open Access Statement: This is an Open Access article distributed in accordance with the Creative Commons Attribution-NonCommercial-NoDerivs 4.0 International License (CC BY-NC-ND 4.0), which permits the noncommercial replication and distribution of the article with the strict proviso that no changes or edits are made and the original work is properly cited (including links to both the formal publication through the relevant DOI and the license). See: https://creativecommons.org/licenses/by-nc-nd/4.0/.

\section{References}

1. Parisi M, Glass I. Joubert Syndrome. 2003 Jul 9 [updated 2017 Jun 29]. In: Adam MP, Ardinger HH, Pagon RA, Wallace SE, Bean LJH, Stephens K, Amemiya A, editors. GeneReviews ${ }^{\circledR}$ [Internet]. Seattle (WA): University of Washington, Seattle; 1993-2020.

2. Parisi MA, Doherty D, Chance PF, Glass IA. Joubert syndrome (and related disorders) (OMIM 213300). Eur J Hum Genet 2007;15:511-21.

3. Nuovo S, Bacigalupo I, Ginevrino M, Battini R, Bertini E, Borgatti R, Casella A, Micalizzi A, Nardella M, Romaniello R, Serpieri V, Zanni G, Valente EM, Vanacore $\mathrm{N}$, Group JSIS. Age and sex prevalence estimate of Joubert syndrome in Italy. Neurology 2020;94:e797-e801.

4. Radha Rama Devi A, Naushad SM, Lingappa L. Clinical and Molecular Diagnosis of Joubert Syndrome and Related Disorders. Pediatr Neurol 2020;106:43-9.

5. Fleming LR, Doherty DA, Parisi MA, Glass IA, Bryant J, Fischer R, Turkbey B, Choyke P, Daryanani K, Vemulapalli M, Mullikin JC, Malicdan MC, Vilboux T, Sayer JA, Gahl 
WA, Gunay-Aygun M. Prospective Evaluation of Kidney Disease in Joubert Syndrome. Clin J Am Soc Nephrol 2017;12:1962-73.

6. Poretti A, Snow J, Summers AC, Tekes A, Huisman T, Aygun N, Carson KA, Doherty D, Parisi MA, Toro C, Yildirimli D, Vemulapalli M, Mullikin JC, Program NCS, Cullinane AR, Vilboux T, Gahl WA, Gunay-Aygun M. Joubert syndrome: neuroimaging findings in 110 patients in correlation with cognitive function and genetic cause. J Med Genet 2017;54:521-9.

7. Bachmann-Gagescu R, Dempsey JC, Phelps IG, O’Roak BJ, Knutzen DM, Rue TC, Ishak GE, Isabella CR, Gorden N, Adkins J, Boyle EA, de Lacy N, O'Day D, Alswaid A, Ramadevi AR, Lingappa L, Lourenco C, Martorell L, Garcia-Cazorla A, Ozyurek H, Haliloglu G, Tuysuz B, Topcu M, University of Washington Center for Mendelian G, Chance P, Parisi MA, Glass IA, Shendure J, Doherty D. Joubert syndrome: a model for untangling recessive disorders with extreme genetic heterogeneity. J Med Genet 2015;52:514-22.

8. Doherty D, Parisi MA, Finn LS, Gunay-Aygun M, AlMateen M, Bates D, Clericuzio C, Demir H, Dorschner M, van Essen AJ, Gahl WA, Gentile M, Gorden NT, Hikida A, Knutzen D, Ozyurek H, Phelps I, Rosenthal P, Verloes A, Weigand H, Chance PF, Dobyns WB, Glass IA. Mutations in 3 genes (MKS3, CC2D2A and RPGRIP1L) cause $\mathrm{COACH}$ syndrome (Joubert syndrome with congenital hepatic fibrosis). J Med Genet 2010;47:8-21.

Cite this article as: Tian C, Chen J, Ming X, Zeng X, Wang R. A 10-year-old girl with Joubert syndrome and chronic kidney disease and its related complications. Quant Imaging Med Surg 2021;11(9):4223-4226. doi: 10.21037/qims-20-943
9. Wolf MT, Saunier S, O'Toole JF, Wanner N, Groshong T, Attanasio M, Salomon R, Stallmach T, Sayer JA, Waldherr R, Griebel M, Oh J, Neuhaus TJ, Josefiak U, Antignac C, Otto EA, Hildebrandt F. Mutational analysis of the RPGRIP1L gene in patients with Joubert syndrome and nephronophthisis. Kidney Int 2007;72:1520-6.

10. Delous M, Baala L, Salomon R, Laclef C, Vierkotten J, Tory K, Golzio C, Lacoste T, Besse L, Ozilou C, Moutkine I, Hellman NE, Anselme I, Silbermann F, Vesque C, Gerhardt C, Rattenberry E, Wolf MT, Gubler MC, Martinovic J, Encha-Razavi F, Boddaert N, Gonzales M, Macher MA, Nivet H, Champion G, Bertheleme JP, Niaudet P, McDonald F, Hildebrandt F, Johnson CA, Vekemans M, Antignac C, Ruther U, Schneider-Maunoury S, Attie-Bitach T, Saunier S. The ciliary gene RPGRIP1L is mutated in cerebello-oculo-renal syndrome (Joubert syndrome type B) and Meckel syndrome. Nat Genet 2007;39:875-81.

11. Romani M, Micalizzi A, Valente EM. Joubert syndrome: congenital cerebellar ataxia with the molar tooth. Lancet Neurology 2013;12:894-905.

12. Bosemani T, Orman G, Boltshauser E, Tekes A, Huisman TA, Poretti A. Congenital abnormalities of the posterior fossa. Radiographics 2015;35:200-20.

13. Abdel Razek AA, Castillo M. Magnetic Resonance Imaging of Malformations of Midbrain-Hindbrain. J Comput Assist Tomogr 2016;40:14-25. 